UDC $81 ` 367.635$

DOI: $10.24045 / f v .2017 .2 .2$

\title{
THE ACTUALITY FUNCTION \\ OF THE PARTICLE WITHIN THE TEXT
}

V. N. Jafar-zadeh

$P h D$

Baku State University

Baku, Azerbaijan

\begin{abstract}
In this article, text-generating means are expressed. Moreover, the particles as the text-generating formal-grammatical element are expressed. The actuality and means generating it are stated. The functions of all types of particles that forming actuality is reviewed together with the relevant text examples. The role of all types of the particles is explained within the text.
\end{abstract}

Keywords: text syntax; text components; the relation of the text; formal-grammatical elements; actualization; particle.

Introduction. There exist various types of relations between text forming units. The sentences do not only make a sequencein any text. The relation between sententences of text occurs when the constituent of sentence is either used in the same way in other following sentences or replaced with another constituent which is semantically and grammatically similiar with it.The usage of these relations in the text appears in the result of repetition of the devices which are used in the sentences following each other and serving the same purpose of these devices in terms of both form and meaning. Lexical devices are the devices which make up a certain type of relations between sentences.The above mentioned devices create the main frame for text forming.

The main term of text forming is the interrelation of sentences that the text contains. This interrelation is realized by the sequence of sentences which are connected with each other by conjunctive devices or asyndetically in a certain way $[1$, p. 127-128].

N. Novruzova who deals with devices stipulating interrelation of text distinguishes three types of devices: lexical, morphological, and syntactical. She gives broad information about pronouns while dealing with lexical devices. She mentions conjunction, particle and modal words as morphological devices that make this relation. She generalizes repetition, position of the sentences and word order in the sentences which forms a text as syntactical devices [2, p. 69-116].

A. Y. Mammadov who deals with formal cohesive devices in text forming distinguishes them into the following groups: grammatical devices, lexical cohesion, phonetic repetition, morphological repetition, lexical repetition, syntactic repetition and gives vast 
information about repetition [3, pressive means of different semantic p. 204-205].

and grammatical relations and take

Formal-grammatical elements play an important role in text forming. When dealing with formalgrammatical elements, parts of speech that serve to form relations in the text are meant. Mostly, pronouns, adverbs, conjunctions, particles and modal words are considered as text forming devices. Demonstrative pronouns are mainly considered to be more efficient from this point of view. It is necessary to note that the role of pronouns is much more than repetitions and synonyms in binding sentences together closely [4, p. 57].

Particles serve to associate components in the text, give semantic nuances from different aspects and express attitude to the idea, and provide the formation of a text more comprehensive and logical. Particles create actualization in a sentence in which they are used, and play an actualization role in associating components that a text contains.

K. M. Abdullayev, a linguist who deals with the function of actualization of particles in text mentions $d a, d \partial$, belo, lap, ancaqas particles, as reciprocal pronouns, yalniz, faqat, təkco as functional words, qadər, kimi as adjuncts, albatto as modal word while speaking about the words which carry the function of actualization in Azerbaijani [5, p. 82-88].

The main part. Particles take different positions within a text; as a formal and grammatical element between components, as an intensifying device of components, as a morphological element that specifies and restricts meaning of text, etc. Particles are expart in forming coherent texts directly. From this point of view, particles have different types of meaning and each of them gives peculiar colorfulness to the text in which they are used, serves to make sentences logical and expression fluent. In this sense, the text forming function of particles will be looked through separately. We will also pay attention to the text forming features of particles to explain more clearly and in detail according types of their meaning.

Intensifying particles: axl, $k i,(\partial n)$ lap, ha, hatta, belo, elo, artıq, daha, bir, birco, da, do, ca, cə. This type of particles intensifies the idea expressed in the text, distinguishes the component in which it is used from other sentences, enhances the strength of the meaning and leads to reveal the main idea easily. It serves to the cohesion between components which comprise the text from the aspect of form.

The actualization role of the participle "axı" is an undeniable fact. It realizes cohesion between the components within the text, enables intensification of the idea expressed after it. Its text forming function is free; it can be placed in any positioning a syntactic whole.

- Axl, ay Madina, müharibə bizim taraflara da galib çatıb. Yolumuza bir bomba düşar!

- Qorxma naynacan! Ela şey ola bilmaz! Dünyanın on güclü dövlatlari bela razılığa galiblar ki, mühariba şraitindo do dinc shali toxunulmazdir. [from "Özga millat" by Yusif $\mathrm{Ha}$ sanbey, p. 197]! 
In the given example the particle "axı" while being used in the first sentence of the text emphasizes the content, makes the idea more precise and binds it with the previous text as well.

The particle "axi" has derived from the word "axir" and when used in the position of particle it means "result", "consequence". It has changed gradually its form as a result of dropping the last consonant. It intensifies the meaning of the text whose components are connected by this particle, makes the expressed idea more exact. Both particles give the text explanative intonation.

Ey gözlari callad, kirpiyi almas,

Gör nə derəm, bir sözümə qulaq as! Axır sana man eylaram iltimas,

Buraya tok naz istomoz, bari bax! [from" Qossmalar" by M. P. Vaqif]

The particle "ki" is placed in the middle or at the end of the sentence according to its position within the components of text. It also emphasizes the meaning expressed in the text. The particle "lap" carries the same semantic and functional features with the particle "ki" and both function as a means of actualization in the text.

Qotazlı dava ki karvanin lap başında uzun boynunu şastla bir az da uca tutub ayaqlarin ata-ata sarvan Qarasuvarlının atı ilo yanaşı gedirdi, bir addım daha atdl, qabă̆a keçdi, să̆a döndü, ela dönmayila da birdon-bira daha göza görünmadi, yox oldu. Sarvan Qarasuvarlı da bununla barabar yox oldu. Xacə İbrahim ağa ki Qotazlı dəvəni bilarəkdən uzaqdan gözdən qoymurdu, tez atını Karvanbaşının atına yaxınlaşdırdı [from Sehrbazlar darasi, by K. Abdulla p. 26-27].
In the example "ki" is followed by names in both cases and causes the pronunciation of the preceding words under the stress. We obviously distinguish between the particle "ki" and the conjunction "ki" according to their function of forming actualization. This conjunction is separated in the text by a comma.

Intensifying particles emphasize the meaning of words or word combinations which constitute the components of text, or generally of the components. So, particles emphasize expressiveness of word, word combination or sentence to which they refer a bit more than other components of the text, specify the meaning and allows more emotional expression of the idea compared to other sentences. Particles differentiate the sentence in which they are used from other sentences. Particles act both as a text forming morphological element and as a means of providing significative expression of coherence within the text.

Specifying particles (elə, məhz, əsl, -ca, -cə).Specifying particles as formal and grammatical elements of text forming explains and clarifies the meaning of the word which they belong to. They stipulate the pronunciation of the word to which is referred under the stress. In general, it does not impact only the meaning of word or expression, but also the meaning of components forming complex syntactic whole.

Taxminan, bir hafta avval Şövqi hayatında çox vacib bir qarar verdi. Artıq bütün gücünü, aslinda, azabını vo maşaqqatini bir yero toplayıb inandı ki, daha doğrusu, 
özünü inandırdl ki, bu ă̆lr, ă̆lası̆̆maz cinayəti heç bir başqa adam yox, məhz o, Şövqi töradib [from Edam vaxtını dayişmək olmaz (story), by K. Abdulla].

The specifying particle "məhz" which stands at the beginning and the end of the given text influences the common meaning of the text. The particle placed at the beginning determines the identity of the person about who is spoken. However, there are some formal and grammatical elements of text forming; only the specifying article "mahz" actualizes the meaning.

Restrictive particles (yalnız, ancaq, bircə, təkcə, elə). Restrictive particles which are one of the means connects the constituents of complex syntactic whole stand before word or word combination which they qualify and limit the meaning of the text. This feature distinguishes restrictive particles from intensifying and specifying particles from the semantic point of view.

The particles "ancaq", "takcə" serve to bind the sentences together which make up the text. The pronoun səni replacing the word "Beyrok" is restricted by using both the particles "ancaq" and "tokco" several times and pronounced under a specific stress.

- Ah, canım, ah, gözüm. Beyrayim, Beyrayim, manim Beyrayim. Sani sevdim.Heç kimsana gözüma görünmadi, sani, ancaq sani, takca sani.Gözüm gördü.Könlüm sevdi. [from "Yarımçıq alyazma", by K. Abdulla, p. 77].

Question particles (ki, bəs, məgər, yəni, ha, -mı, -mi, -mu, -mü) are frequently used in the Azerbaijani language and appear in interroga- tive sentences. We will look through "-mı" (-mi, -mu, -mü) as a question particle. Being one of the functional parts of speech it is added to the words which function as parts of the sentences and express the question in the sentence. The place of the particle with the word which it is added can be anywhere in the sentence and it has different syntactical functiont. As the particle “-mi”, (-mi, -mu, -mü) became an affix, it had been considered as an interrogative ending for a while. Undoubtly, it can be considered as an affix because of adjoiningthe end of words and appearing in the language in the form of affix. On the other hand, it can not be regarded only as an interrogative ending of only one part of speech (ex: as an ending of the verb) since it can be added not only to one part of speech but also to all the notional parts of speech and express interrogation or turn the whole sentence into an interrogative sentence. It should be called as an affix-particle [6, p. 259].

- Kapitanın kayutuna! - deyə çamadanı göstordi.

Kayutun qapısı yarıörtülü idi. Içəridən çıxan acı tüstü adamı uzaqdan vururdu. Hardon lap darinlardan qopub galon öskürək dahlizi başına götürürdü. Man yanılmamışdım ki? Eşitdiyimo göro bela qoca olmasin garak “Kompozitor"un kapitanı! Amma yox, manimki gatirmadi deyəsan! Tünd adama oxşayır! Yoxsa bu qador papiros çəkərdimi? Açı̆̆ını deyim, içəri girmaya ehtiyat elayirdim.[from "Sualtı döyüşlar", by Y. Hasanbey, p. 8]. 
Imperative particles (bax, gəl, gəlsən, gələsən, gəlsənə, gəlin, gələsiniz, qoy, qoyun, gör, görün, görək, görsün, ha, da, də, di, -sana, -sənə) express wish, advice, instance, warning etc. in complex syntactic whole, the components of which are linked to each other by them.Imperative particles have various types based upon their formal and grammatical structure;particles used as particles, notional parts of speech and affixes at the same time.

The particle "gəlsənə"differs from others as there exist particles such as "gəl”, "sənə”, "gəlsənə" seperately. It is necessary to differ them in the text. The particle "gəlsənə" in the following text sample gives distinctive meaning to the text.

Neça saatdan sonra Mirza Әsgar yuxudan qalxdl, yemək stoluna yanaşıb talab eladi:

- Arvad, mana yemak ver, yaman acmişam! Qadın kişisinin ömründo görmadiyi şirin bir iştahla xörak yediyini görüb sevindi.

- Ay Mirza, - dedi, - ăğr işs sana düşüb, galsana hesab-kitabı buraxıb, stansiyada iş götürasan? [from "Özündən naxoş”, by Mir Colal, p. 123].

Particles expressing desire and condition (kaş, kaş ki, təki, bari, bir, nə ola) are found in the sentences with a verbal predicate. It gives the text different semantic meaning. The predicate of the sentences with this kind of particles is expressed by the verbs in the subjunctive and imperative form. In this respect, particles give the sentence semantic shades: hopeful, wistful or regretful
wish.If the predicate of the sentence is imperative, it means hope for the realization of the wish, but if it is subjunctive, it signifies regret.

...Ela da olsa, bela da olsa, yena manim evim ylxılmayacaqmı?Oğlumquzım düzda qalmayacaqmı?Na bilim vallah, heç özün do bu işlardən baş açmıram.Kaş yaranmayaydım. Allah məni bura gatiran günə daş yağdıraydı" [from "Doli Kür", by I. Shikhli, p. 37].

Result. Dealing with the structure of the sentence its two characteristic features are mentioned. Namely, it deals with two different types of division. One of them is a grammatical division according to parts of sentence in the syntactical level. The other is an actual division regarded as a specific division. Actual division is based on logical categorization of the sentence. The terms "logical subject" and "logical object" are used instead of the terms "subject" and "predicate". Here the analysis of suprasyntax, the units larger than sentences is remarkably paid attention to. After the analysis of the suprasyntax the devices forming actualization are involved in the analysis. Under the term actual division the principle of relevance between actualized and non-actualized components is meant. The actualization of any component of the sentence differentiates it from other components logically and semantically. This actualization is realized by different types of devices. The most frequently used of these devices is particles. 


\section{Bibliography}

1. Wintemann G. Re-weighting as textual stimuli. - Munchen, 1972.

2. Novruzova N. Textsyntax. - Baku, 2002.

3. Abdulla K., Mammadov A. Y., Musayev M. M., Ustunova K., Novruzova N. etc. Complex syntactic intact in Azerbaijani language. - Baku, 2012.

4. Solganik G. Y. Syntactic stylistics. Moskva, 1991.

5. Abdullaev K. M. Actual division of the sentence in the Azerbaijani language // Soviet Turkology. - 1983. - № 1 .

6. Huseynzada M. Modern Azerbaijan language : morphology. - Baku, 2007.
7. Yusif Hasanbey. "Another Nation". Baku, 2013.

8. Molla Panah Vagif. "Attachments". Baku, 2004.

9. Kamal Abdulla. "Wizards valley". - Ba$\mathrm{ku}, 2006$.

10. Kamal Abdulla. "Execution date can not be changed". - Baku, 2015.

11. Kamal Abdulla. "Incomplete manuscript". - Baku, 2004.

12. Yusif Hasanbey. "Underwater fights". Baku, 2013.

13. Mir Colal. "Unwholesome". - Baku, 2005.

14. Ismayıl Shikhli. "Tempestuous Kura". Baku, 2005.

(C) Jafar-zadeh V. N., 2017. 